\title{
AKTIVITAS ANTAGONISTIK BAKTERI SELULOLITIK ASAL RHIZOSFER KELAPA SAWIT (Elaeis guineensis Jacq.) TERHADAP Ganoderma boninense Pat.
}

\section{ANTAGONISTIC ACTIVITY OF CELLULOLYTIC BACTERIA FROM OIL PALM RHIZOSPHERE (Elaeis guineensis Jacq.) AGAINST Ganoderma boninense Pat.}

\author{
Miratun Nisa, Fitratul Aini, Hasna Ul Maritsa* \\ Program Studi Biologi Fakultas Sains dan Teknologi Universitas Jambi, Jl.Jambi-Ma. Bulian Km 15 Mendalo Darat \\ Jambi 36361 \\ *Corresponding author: hasnaul.maritsa123@gmail.com
}

\begin{abstract}
Abstrak
Penyakit busuk pangkal batang pada kelapa sawit (Elaeis guineensis Jacq.) disebabkan oleh Ganoderma boninense Pat. Bakteri selulolitik dari rizosfer kelapa sawit dapat dijadikan agen hayati dalam menghambat pertumbuhan $G$. boninense. Penelitian ini bertujuan untuk mendapatkan bakteri selulolitik dari rizosfer kelapa sawit dan menentukan efektivitasnya dalam menghambat pertumbuhan $G$. boninense. Tahap penelitian meliputi pengambilan sampel dari rizosfer kelapa sawit, isolasi, pemurnian, uji aktivitas selulolitik, dan uji daya hambat terhadap G. boninense serta identifikasi isolat bakteri yang potensial. Indeks selulolitik bakteri ditentukan dengan pewarnaan congo red $0,1 \%$. Aktivitas penghambatan dilakukan dengan menentukan persentase daya hambat bakteri dalam menghambat $G$. boninense. Uji efektivitas dengan membandingkan hasil uji T pada taraf 5\%. Hasil menunjukkan bahwa dari rizosfer kelapa sawit diperoleh 19 isolat bakteri selulolitik dengan indeks selulolitik tertinggi 4,38 pada isolat LBS1. Berdasarkan uji T dari efektivitas bakteri selulolitik terhadap $G$. boninense menunjukkan 6 isolat bakteri (LBS3, LBS4, DBS1, DBS7, SBS2 dan SBS6) memiliki nilai efektif atau berpotensi sebagai antagonis dengan persentase daya hambat tertinggi sebesar 40,17\% isolat DBS1 yang merupakan genus Flavobacterium. Bakteri selulolitik yang diperoleh diharapkan dapat dijadikan agen biokontrol terhadap $G$. boninense di masa depan
\end{abstract}

Kata kunci: Antagonis; Flavobacterium; Jamur patogen; Selulase

\begin{abstract}
Basal stem root disease in oil palm tree (Elaeis guineensis Jacq.) is caused by Ganoderma boninense Pat. infection. Cellulolytic bacteria from rhizosphere can be used as agents to inhibit growth of G. boninense as pathogenic fungi. Purpose of the research is to obtain cellulolytic bacteria from oil palm tree rhizosphere and to determine their effectiveness in inhibiting $G$. boninense growth. The research stages included sampling from the oil palm tree rhizosphere, isolation, purification, cellulolytic activity test and dual culture test against $G$. boninense and identification of effective isolates. The cellulolytic index of bacteria was determined by congo red $0.1 \%$. The antagonistic test was conducted to determine presentation of isolate bacteria in inhibit G. boninense and effectiveness test by comparing the result of T-test at the level 5\%. The results showed that there were 19 isolates of cellulolytic bacteria from oil palm tree rhizosphere with highest cellulolytic index 4.38 (isolates LBS1). Based on the T-test of the effectiveness cellulolytic bacteria against G. boninense, it showed 6 isolates (LBS3, LBS4, DBS1, DBS7, SBS2, and SBS6) had effective values or potential antagonists with highest percentage inhibition $40.17 \%$ isolate DBS1 genus of Flavobacterium. Iin the future, cellulolytic bacteria obtained can be used as biocontrol agents for G. boninense.
\end{abstract}

Keywords: Antagonist; Cellulase; Flavobacterium; Fungal Pathogen

Permalink/DOI: http://dx.doi.org/10.15408/kauniyah.v13i1.11704 


\section{PENDAHULUAN}

Kelapa sawit (Elaeis guineensis Jacq.) merupakan salah satu tanaman yang menghasilkan minyak nabati. Produktivitas tanaman kelapa sawit dipengaruhi oleh beberapa faktor, salah satunya yaitu penyakit busuk pangkal batang (BPB) yang disebabkan oleh Ganoderma boninense Pat. Jamur patogen G. boninense merupakan salah satu spesies Basidiomycota yang dapat hidup pada sisa tanaman mati (saprofit fakultatif) dengan memanfaatkan sisa-sisa tanaman berupa selulosa. Sisa tanaman sawit dapat menjadi sumber nutrisi untuk jamur patogen dan menjadi sumber inokulum penyakit (Ali, Yaacob, Seman, \& Wahid, 2004).

Upaya pengendalian hayati terhadap $G$. boninense dengan memanfaatkan agen antagonis berupa bakteri selulolitik. Bakteri selulolitik ialah bakteri yang berperan dalam mendegradasi selulosa dengan melibatkan beberapa aktivitas enzim, yaitu endo- $\beta 1.4-$ glukanase, ekso- $\beta 1.4$-glukanase, dan $\beta$ glukosidase sehingga dapat mempersingkat proses dekomposisi dari bahan organik berupa selulosa menjadi oligosakarida yang lebih kecil dan akhirnya menjadi glukosa (Rahayu, Yahyani, \& Puspita, 2014). Pemanfaatan mikroba selulolitik mampu menjadi kompetitor langsung dari patogen, salah satunya $G$. boninense dalam hal kompetisi akan nutrisi berupa selulosa, sehingga dapat mencegah $G$. boninense tidak dapat memanfaatkan selulosa pada akar dan pangkal batang kelapa sawit (Wafa, 2017).

Penelitian yang berkaitan dengan pemanfaatan bakteri selulolitik, diantaranya Stenotrophomonas rhizophila yang merupakan mikroba endofit mampu menghambat pertumbuhan $G$. boninense sebesar $63 \%$ dan menghasilkan enzim selulase dengan indeks selulase sebesar 0,46 (Rupaedah et al., 2018). Selain itu, Bacillus cereus dan B. thuringiensis hasil isolasi tanah perkebunan kelapa sawit dan karet di sekitar kawasan hutan Taman Nasional Bukit Duabelas Jambi mampu menghambat Curvularia sp. sebesar $57,5 \%$ dan Colletotrichum sp. sebesar $60 \%$ yang menginfeksi tanaman kelapa sawit, menyebabkan penyakit antraknosa dan hawar daun (Purnamasari, 2013). Penelitian bakteri selulolitik terhadap $G$. boninense yang berasal dari rizosfer kelapa sawit belum banyak dilakukan, terutama penelitian dari perkebunan sawit di Provinsi Jambi. Tujuan dari penelitian ini untuk mendapatkan bakteri selulolitik dari rizosfer kelapa sawit (E. guineensis Jacq.) dan mengetahui efektivitasnya terhadap pertumbuhan $G$. boninense.

\section{MATERIAL DAN METODE}

Isolat Ganoderma boninense diperoleh dari Indonesian Oil Palm Research Institute (IOPRI), Medan.

\section{Pengambilan Sampel Rizosfer Kelapa Sawit (Elaeis guineensis Jacq.)}

Pengambilan sampel dilakukan bulan Juni dari sekitar perakaran kelapa sawit yang sehat di PT. Niaga Guna Kencana Sawit berumur 8 dan 11 tahun dan PT. Perkebunan Nusantara VI Jambi berumur 14 tahun pada kedalaman 0-15 cm dari permukaan tanah (top soil) (Wafa, 2017). Namun sebelumnya, diukur suhu tanah dengan soil thermometer, pengukuran $\mathrm{pH}$ tanah, dan kelembapan tanah dengan soil tester yang dianalisis langsung di lapangan.

\section{Isolasi Bakteri dan Skrining Bakteri Selulolitik dari Rizosfer}

Sebanyak $1 \mathrm{~g}$ tanah dan akar tanaman yang melekat di permukaan akar dimasukkan dalam tabung reaksi berisi $10 \mathrm{~mL}$ akuades steril (pengenceran $10^{-1}$ ) dan dihomogenkan dengan menggunakan vortex. Pengenceran dilakukan hingga $10^{-5}$, dari pengenceran $10^{-1}$ diambil sebanyak $1 \mathrm{~mL}$ dan dipindahkan ke dalam tabung reaksi yang telah diisi akuades steril sebanyak $9 \mathrm{~mL}$. Diambil $0,1 \mathrm{~mL}$ dari masing-masing tabung $10^{-4}$ dan $10^{-5}$ untuk dikultur pada media Carboxy Methyl Cellulose Agar (CMCA) dengan 3 kali pengulangan, kemudian sampel disebar dengan menggunakan batang $\mathrm{L}$ dan diinkubasi pada suhu $30{ }^{\circ} \mathrm{C}$ (Modifikasi dari Seprianto, 2017).

Isolat diinokulasi menggunakan metode titik ke dalam media CMCA dan diinkubasi pada suhu $30{ }^{\circ} \mathrm{C}$. Aktivitas selulolitik bakteri diindikasikan dengan terbentuknya zona bening di sekitar koloni setelah sebanyak $2 \mathrm{~mL}$ larutan congo red $0,1 \%$ dituangkan ke dalam media yang berisi isolat, kemudian didiamkan 
selama 15 menit. Larutan dibuang, kemudian dibilas dengan larutan $\mathrm{NaCl} 0,1 \mathrm{M}$, setelah itu diamati keberadaan zona bening. Indeks aktivitas selulase ditentukan pada rasio diameter zona bening dengan diameter koloni (Nurfitriani \& Handayanto, 2017). Indeks selulolitik = diameter zona bening $(\mathrm{mm})$ diameter koloni $(\mathrm{mm})$ / diameter koloni (mm)

\section{Uji Daya Hambat Bakteri Selulolitik terhadap Ganoderma boninense secara In Vitro.}

Inokulum $G$. boninense diinokulasikan pada media PDA + CMC (Potato Dextrose Agar $39 \mathrm{~g}$ dan Carboxy Methyl Cellulose $10 \mathrm{~g}$ dalam $1.000 \mathrm{~mL}$ ) hingga berdiameter $\pm 20 \mathrm{~mm}$ dengan jarak $3 \mathrm{~cm}$ dari tepi cawan petri berdiameter $9 \mathrm{~cm}$. Sebanyak 1 ose isolat bakteri selulolitik digoreskan sepanjang $4 \mathrm{~cm}$ secara berlawanan dengan jarak $3 \mathrm{~cm}$ dari jamur patogen dan diinkubasi pada suhu $30{ }^{\circ} \mathrm{C}$. Untuk kontrol, media hanya berisi inokulum $G$. boninense pada salah satu sisinya (Fokkema, 1973). Setiap jenis bakteri selulolitik diuji dengan pengulangan 3 kali. Pengamatan dilakukan selama 7 hari setelah inokulasi dengan mengukur diameter koloni $G$. boninense pada kontrol (R1) dan diameter koloni $G$. boninense pada perlakuan (R2). DH (daya hambat $(\%)$ ) $\mathrm{R} 1$ (diameter pertumbuhan patogen pada kontrol) - R2 (diameter patogen pada cawan uji) / R1 (diameter pertumbuhan patogen pada kontrol) $\mathrm{x} 100 \%$.

Persentase penghambatan didasari oleh growth inhibition category (GIC), dengan skala 0-4 (Živković et al., 2010). Kategori tersebut yaitu: Skala $0=$ tidak ada penghambatan pertumbuhan patogen; Skala 1 $=1-25 \%$ penghambatan pertumbuhan patogen; Skala $2=26-50 \%$ penghambatan pertumbuhan patogen; Skala $3=51-75 \%$ penghambatan pertumbuhan pathogen; dan Skala $4=76$ $100 \%$ penghambatan pertumbuhan patogen.

Penentuan kategori kemampuan antagonis dikelompokkan menjadi empat kategori berdasarkan persentase zona penghambatan (Prastya, Agung, \& Endang, 2014) yaitu: Kuat (>40\%) dengan simbol +++; Sedang $(40 \%<x>30 \%)$ dengan simbol ++ ; Lemah $(<30 \%)$ dengan simbol + ; dan Tidak menghambat $(0 \%)$ dengan simbol -.

\section{Identifikasi Bakteri Selulolitik yang Efektif Menghambat Ganoderma boninense}

Identifikasi bakteri berdasarkan pengamatan morfologis meliputi bentuk, tepi, permukaan, ukuran, elevasi, dan warna koloni. Sifat fisiologis meliputi pewarnaan gram bakteri, dan uji biokimia yaitu uji katalase, motilitas, TSIA, Mac Conkey, Simmons Citrate, dan uji urea (Kasana, Richa, Hena, Som, \& Arvind, 2008). Data hasil pengujian bakteri disajikan dalam bentuk tabel dan gambar. Karakterisasi bakteri disesuaikan dengan buku identifikasi Bergey's Manual of Determinative Bacteriology dari Holt, Krieg, Sneath, Staley, dan Williams (1994) berdasarkan karakter morfologi maupun fisiologi.

\section{Analisis Data}

Data yang diperoleh dari uji daya hambat bakteri selulolitik dengan $G$. boninense dianalisis dengan uji $\mathrm{T}$ pada taraf $5 \%(0,05)$, bertujuan untuk membandingkan daya tumbuh $G$. boninense yang di uji dengan $G$. boninense kontrol sehingga dapat diketahuipotensi antagonis bakteri selulolitik. Nilai efektif jika diameter koloni Ganoderma boninense pada media uji lebih kecil dibandingkan dengan kontrol (Tirtana, Sulistyowati, \& Cholil, 2013).

\section{HASIL}

\section{Isolasi Bakteri Selulolitik Rizosfer Kelapa Sawit (Elaeis guineensis Jacq.)}

Hasil isolasi dari rizosfer kelapa sawit diperoleh sebanyak 19 isolat kandidat bakteri selulolitik. Perbedaan karakteristik morfologi meliputi bentuk, warna, ukuran koloni, elevasi, dan tepi, serta permukaan dari isolat bakteri tersebut. Masing-masing lokasi memiliki jumlah isolat kandidat bakteri selulolitik yang berbeda-beda ditunjukkan Tabel 1 .

Keberadaan bakteri selulolitik di rizosfer dipengaruhi oleh beberapa faktor lingkungan, seperti $\mathrm{pH}$, suhu, dan kelembapan tanah. Pada saat pengambilan sampel telah dilakukan pengukuran faktor fisik kimia tanah. Hasil pengukuran suhu, kelembapan, dan $\mathrm{pH}$ tanah masing-masing lokasi ditunjukkan pada Tabel 2. 
Tabel 1. Karakteristik isolat bakteri selulolitik rizosfer E. guineensis

\begin{tabular}{|c|c|c|c|c|c|c|c|}
\hline \multirow{2}{*}{$\begin{array}{l}\text { Lokasi } \\
\text { pengam- } \\
\text { bilan }\end{array}$} & \multirow{2}{*}{$\begin{array}{l}\text { Kode } \\
\text { isolat }\end{array}$} & \multicolumn{6}{|c|}{ Morfologi koloni bakteri } \\
\hline & & Bentuk & Warna & Ukuran & Elevasi & Tepi & $\begin{array}{l}\text { Permu- } \\
\text { kaan }\end{array}$ \\
\hline \multirow[t]{5}{*}{ I } & LBS1 & $\begin{array}{l}\text { Tidak } \\
\text { beraturan }\end{array}$ & Putih susu & Kecil & Datar & Bergelombang & Kasar \\
\hline & LBS2 & Bulat & $\begin{array}{l}\text { Putih } \\
\text { kekuningan }\end{array}$ & Kecil & Cembung & Rata & Halus \\
\hline & LBS3 & Bulat & $\begin{array}{l}\text { Putih } \\
\text { kekuningan }\end{array}$ & Sedang & Cembung & Rata & Halus \\
\hline & LBS4 & Filiform & Putih susu & Besar & Datar & Bergelombang & Kasar \\
\hline & LBS5 & Bulat & $\begin{array}{l}\text { Putih } \\
\text { kekuningan }\end{array}$ & Titik & Cembung & Rata & Halus \\
\hline \multirow[t]{8}{*}{ II } & DBS1 & Bulat & Putih susu & Kecil & Datar & Rata & Halus \\
\hline & DBS2 & $\begin{array}{l}\text { Tidak } \\
\text { beraturan }\end{array}$ & Putih susu & Sedang & Timbul & Rata & Kering \\
\hline & DBS3 & Bulat & Putih susu & Kecil & Cembung & Rata & Halus \\
\hline & DBS4 & Bulat & $\begin{array}{l}\text { Putih } \\
\text { kekuningan }\end{array}$ & Titik & Cembung & Rata & Halus \\
\hline & DBS5 & Rizoid & Putih susu & Besar & Datar & Bergerigi & Halus \\
\hline & DBS6 & Bulat & Putih susu & Kecil & Datar & Rata & Halus \\
\hline & DBS7 & Bulat & $\begin{array}{l}\text { Putih } \\
\text { kekuningan }\end{array}$ & Kecil & Cembung & Rata & Halus \\
\hline & DBS8 & Rizoid & Putih susu & Besar & Datar & Filamentous & Halus \\
\hline \multirow[t]{6}{*}{ III } & SBS1 & Bulat & Putih susu & Kecil & $\begin{array}{l}\text { Cem } \\
\text { bung }\end{array}$ & Rata & Halus \\
\hline & SBS2 & Bulat & Putih susu & Titik & Cembung & Rata & Halus \\
\hline & SBS3 & Bulat & $\begin{array}{l}\text { Putih } \\
\text { kekuningan }\end{array}$ & Kecil & Datar & Rata & Halus \\
\hline & SBS4 & Bulat & $\begin{array}{l}\text { Putih } \\
\text { kekuningan }\end{array}$ & Kecil & Cembung & Rata & Halus \\
\hline & SBS5 & Rizoid & Putih susu & Sedang & Datar & Berlekuk & Licin \\
\hline & SBS6 & Bulat & Putih susu & Sedang & Datar & Datar & Kasar \\
\hline
\end{tabular}

Tabel 2. Pengukuran faktor fisik kimia rizosfer kelapa sawit

\begin{tabular}{ccccc}
\hline $\begin{array}{c}\text { Lokasi } \\
\text { pengambilan } \\
\text { sampel }\end{array}$ & Suhu tanah $\left({ }^{\circ} \mathrm{C}\right)$ & $\begin{array}{c}\text { Kelembapan } \\
\operatorname{tanah}(\%)\end{array}$ & $\mathrm{pH}$ tanah & Jumlah isolat \\
\hline I ( PT.NGKS) & 29 & 70 & 6,2 & 5 \\
II ( PT.NGKS) & 28,5 & 70 & 6,8 & 8 \\
III ( PTPN VI) & 28 & 75 & 6,8 & 6 \\
\hline
\end{tabular}

Keterangan: Lokasi I = sawit umur 8 tahun; Lokasi II = sawit umur 11 tahun; Lokasi III = sawit umur 14 tahun

Skrining Bakteri Selulolitik Rizosfer Kelapa Sawit (Elaeis guineensis Jacq.)

Adanya aktivitas selulolitik dari bakteri rizosfer ditunjukkan dengan terbentuknya zona bening pada media CMCA setelah diberi pewarna congo red (Gambar 1). Zona bening yang terbentuk diakibatkan oleh proses degradasi selulosa oleh bakteri selulolitik. Aktivitas selulolitik tiap isolat dapat terlihat jelas diamati dan diukur dengan jangka sorong. 


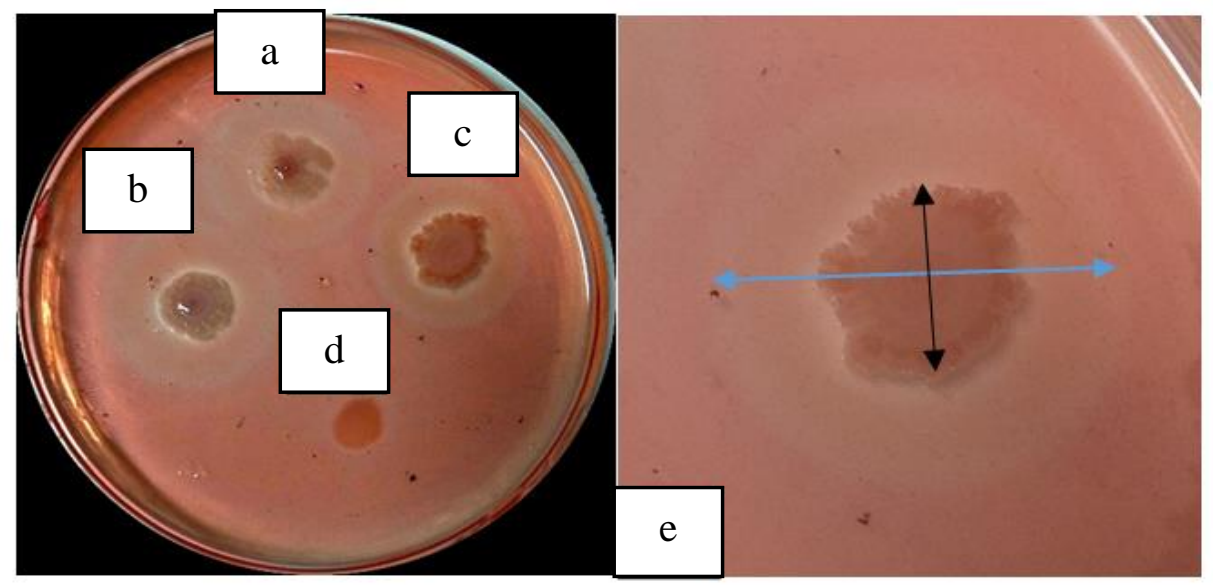

Gambar 1. Uji aktivitas selulolitik terhadap (a) isolat SBS1, (b) SBS2, (c) DBS8 menunjukkan adanya zona bening, (d) LBS5 tidak menunjukkan adanya zona bening. Perhitungan indeks selulolitik (e). Diameter koloni bakteri $(\uparrow)$ dan diameter zona bening $(\leftrightarrow)$

Kemampuan bakteri
menghidrolisis selulosa dinyatakan dalam
bentuk indeks aktivitas selulolitik (IAS).
Perhitungan nilai IAS dilakukan berdasarkan
diameter zona bening yang terbentuk dan
diameter koloni isolat bakteri (Tabel 3). Hasil
uji aktivitas selulolitik menunjukkan bahwa
dari 19 isolat bakteri diperoleh 2 isolat
menunjukkan aktivitas selulase yang tinggi
dengan indeks selulolitik yaitu 4,38 pada isolat
LBS1 dan 2,81 isolat DBS6. Untuk 10 isolat
lainnya menunjukkan aktivitas selulase yang
sedang dan 7 isolat memiliki indeks selulolitik
yang rendah.

\section{Uji Daya Hambat Bakteri Selulolitik Rizosfer Kelapa Sawit terhadap Ganoderma boninense}

Hasil uji antagonis menunjukkan bahwa dari 16 isolat bakteri selulolitik diantaranya sebanyak 15 isolat memiliki kemampuan dalam menghambat pertumbuhan $G$. boninense dengan aktivitas yang berbeda. Persentase penghambatan tinggi ditunjukkan oleh isolat DBS1 dengan penghambatan sebesar 40,17\%, sedangkan persentase penghambatan pertumbuhan rendah ditunjukkan oleh isolat SBS6 sebesar 13,35\% (Tabel 4).

Tabel 3. Hasil indeks aktivitas selulolitik bakteri rizosfer sawit

\begin{tabular}{cccc}
\hline No & Kode isolat & Indeks aktivitas selulolitik & Kategori \\
\hline 1 & LBS1 & 4,38 & Tinggi \\
2 & LBS2 & 0,73 & Rendah \\
3 & LBS3 & 1,26 & Sedang \\
4 & LBS4 & 1,08 & Sedang \\
5 & LBS5 & 0,00 & Rendah \\
6 & DBS1 & 0,71 & Rendah \\
7 & DBS2 & 0,25 & Rendah \\
8 & DBS3 & 1,46 & Sedang \\
9 & DBS4 & 1,43 & Sedang \\
10 & DBS5 & 1,47 & Sedang \\
11 & DBS6 & 2,81 & Tinggi \\
12 & DBS7 & 1,41 & Sedang \\
13 & DBS8 & 1,87 & Sedang \\
14 & SBS1 & Sedang \\
15 & SBS2 & 1,89 & Sedang \\
16 & SBS3 & 1,59 & Rendah \\
17 & SBS4 & 0,00 & Rendah \\
18 & SBS5 & 0,00 & Sedang \\
19 & SBS6 & 1,57 & Rendah \\
\hline
\end{tabular}


Tabel 4. Daya hambat bakteri selulolitik terhadap G. boninense

\begin{tabular}{|c|c|c|c|c|c|}
\hline No & $\begin{array}{l}\text { Kode } \\
\text { isolat }\end{array}$ & $\begin{array}{c}\text { Daya } \\
\text { hambat }(\%)\end{array}$ & $\begin{array}{c}\text { Nilai } \\
\text { aktivitas }\end{array}$ & Mekanisme & $\begin{array}{c}\text { Hasil mekanisme secara } \\
\text { makroskopis }\end{array}$ \\
\hline 1 & LBS1 & 27,92 & + & Kompetisi & $\begin{array}{c}\text { Diameter G. boninense } \\
\text { mengecil }\end{array}$ \\
\hline 2 & LBS2 & 1,13 & + & Tidak ada & - \\
\hline 3 & LBS3 & 29,45 & + & Kompetisi & $\begin{array}{c}\text { Diameter G. boninense } \\
\text { mengecil }\end{array}$ \\
\hline 4 & LBS4 & 18,85 & + & Antibiosis & Adanya zona bening \\
\hline 5 & DBS1 & 40,17 & +++ & Kompetisi & $\begin{array}{c}\text { Diameter } G \text {. boninense } \\
\text { mengecil }\end{array}$ \\
\hline 6 & DBS2 & 0,89 & + & Antibiosis & Adanya zona bening \\
\hline 7 & DBS3 & 1,37 & + & Antibiosis & Adanya zona bening \\
\hline 8 & DBS4 & 22,04 & + & Antibiosis & Adanya zona bening \\
\hline 9 & DBS5 & 14,20 & + & Kompetisi & $\begin{array}{c}\text { Diameter G. boninense } \\
\text { mengecil }\end{array}$ \\
\hline 10 & DBS6 & 1,16 & + & Antibiosis & Terlihat adanya zona bening \\
\hline 11 & DBS7 & 19,68 & + & $\begin{array}{l}\text { Kompetisi - } \\
\text { Antibiosis }\end{array}$ & $\begin{array}{c}\text { Adanya pengurangan } \\
\text { diameter dan zona bening }\end{array}$ \\
\hline 12 & DBS8 & 12,24 & + & Antibiosis & Adanya zona bening \\
\hline 13 & SBS1 & 17,56 & + & Antibiosis & Adanya zona bening \\
\hline 14 & SBS2 & 21,69 & + & Kompetisi & $\begin{array}{c}\text { Diameter } G \text {. boninense } \\
\text { mengecil }\end{array}$ \\
\hline 15 & SBS5 & 0,00 & - & Tidak Ada & $x_{0}$ \\
\hline 16 & SBS6 & 13,35 & + & Antibiosis & Adanya zona bening \\
\hline
\end{tabular}

Keterangan: $+++=$ kuat; $++=$ sedang; $+=$ lemah; $-=$ tidak menghambat

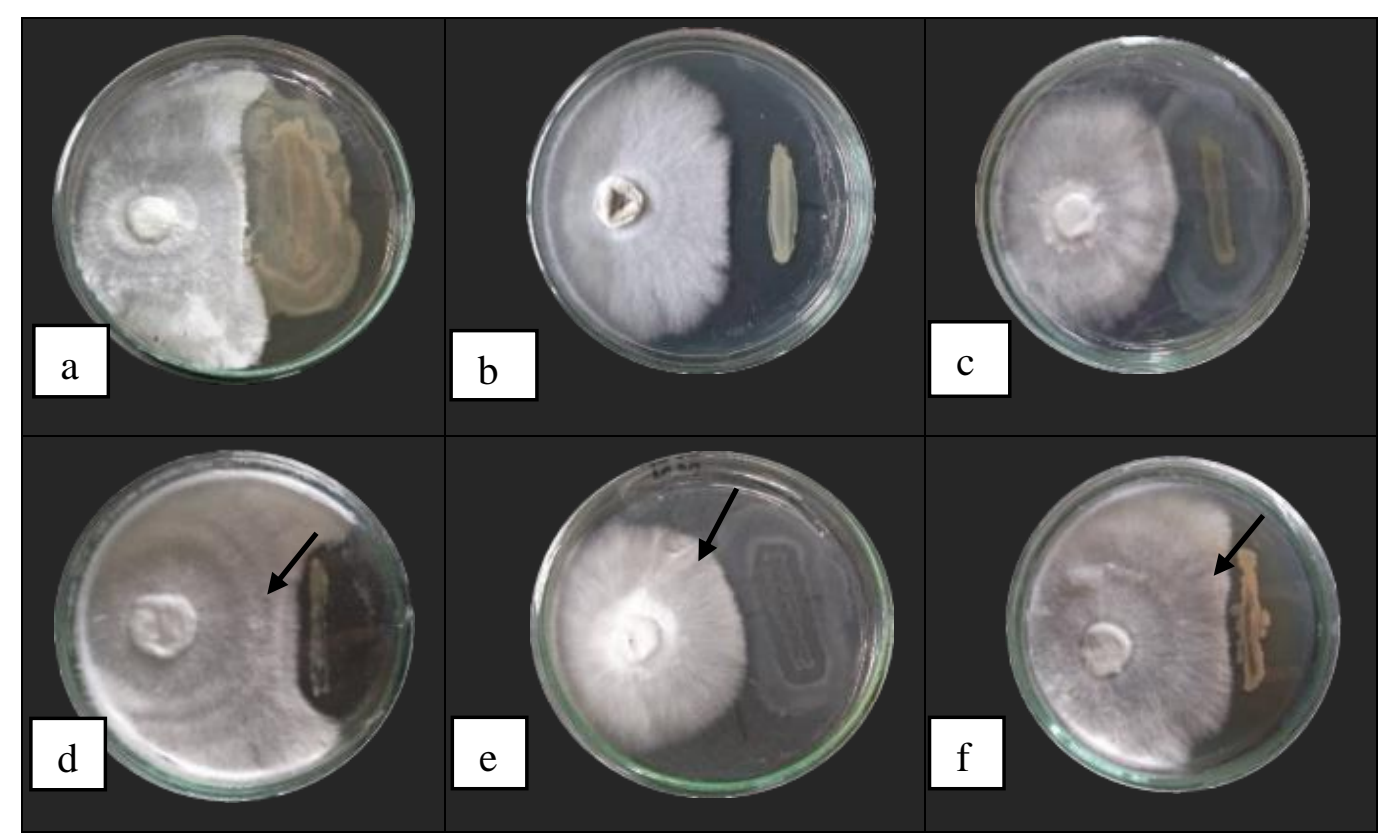

Gambar 2. Mekanisme antagonis isolat bakteri selulolitik; (a) LBS1, (b) DBS1, (c) DBS7 terjadi kompetisi, (d) DBS3, (e) DBS7, (f) DBS8 terjadi antibiosis (Dok.pribadi, 2018)

Pada uji antagonis terlihat bahwa adanya aktivitas dari masing-masing bakteri selulolitik terhadap G. boninense. Mekanisme penghambatan secara makroskopis dari isolat bakteri selulolitik bersifat kompetisi dan antibiosis. Hasil mekanisme yang berbedabeda dari tiap isolat ditunjukkan pada Gambar 2. 
Daya Hambat Isolat Bakteri Selulolitik Rizosfer Kelapa Sawit terhadap Ganoderma boninense (In Vitro Assay)

Untuk menentukkan nilai efektivitas bakteri selulolitik terhadap $G$. boninense dari nilai persentase penghambatan dan hasil uji $\mathrm{T}$, membandingkan diameter kontrol dengan diameter pada uji antagonis pada taraf kesalahan $5 \%(0,05)$. Hasil uji $\mathrm{T}$ dari isolat bakteri selulolitik ditunjukkan pada Tabel 5 .

Tabel 5. Hasil uji T penghambatan bakteri selulolitik terhadap G.boninense

\begin{tabular}{ccccc}
\hline No & Kode isolat & $\begin{array}{c}\text { Rata-rata diameter koloni } G \\
\text { boninense pada } 7 \mathrm{hsi}(\mathrm{mm})\end{array}$ & $\begin{array}{c}\mathrm{T} \\
\text { hitung }\end{array}$ & Nilai efektivitas \\
\hline 1 & Kontrol & $98,75 \pm 0,38$ & & \\
2 & LBS1 & $71,18 \pm 13,73$ & $-3,479^{\mathrm{n}}$ & Tidak efektif \\
3 & LBS2 & $89,08 \pm 8,19$ & $-2,043^{\mathrm{n}}$ & Tidak efektif \\
4 & LBS3 & $69,67 \pm 6,12$ & $-8,226^{*}$ & Efektif \\
5 & LBS4 & $80,13 \pm 5,08$ & $-6,342^{*}$ & Efektif \\
6 & DBS1 & $59,08 \pm 9,39$ & $-7,320^{*}$ & Efektif \\
7 & DBS2 & $97,89 \pm 7,36$ &,$- 202^{\mathrm{n}}$ & Tidak efektif \\
8 & DBS3 & $97,39 \pm 1,013$ & $-2,319^{\mathrm{n}}$ & Tidak efektif \\
9 & DBS4 & $76 ., 98 \pm 11,44$ & $-3,296^{\mathrm{n}}$ & Tidak efektif \\
10 & DBS5 & $88,64 \pm 20,77$ &,$- 843^{\mathrm{n}}$ & Tidak efektif \\
11 & DBS6 & $97,60 \pm 7,54$ &,$- 265^{\mathrm{n}}$ & Tidak efektif \\
12 & DBS7 & $79,32 \pm 3,83$ & $-8,785^{*}$ & Efektif \\
13 & DBS8 & $89,48 \pm 12,93$ & $-1,241^{\mathrm{n}}$ & Tidak efektif \\
14 & SBS1 & $86,61 \pm 28,06$ &,$- 749^{\mathrm{n}}$ & Tidak efektif \\
15 & SBS2 & $77,33 \pm 7,04$ & $-5,267^{*}$ & Efektif \\
16 & SBS6 & $85,57 \pm 2,73$ & $-8,371^{*}$ & Efektif \\
\hline
\end{tabular}

Keterangan: $*=$ signifikan; $\mathrm{n}=$ tidak signifikan

\section{Identifikasi Isolat Potensial Bakteri Selulolitik}

Bakteri selulolitik yang dikategorikan efektif terhadap $G$. boninense, diidentifikasi dengan pengamatan ciri morfologis dilanjutkan karakterisasi berdasarkan pewarnaan gram dan uji sifat biokimia (fisiologi) untuk mengetahui genus dari bakteri tersebut. Berdasarkan kunci determinasi Bergey's isolat LBS3, DBS7 dan
SBS6 merupakan genus Lactobacillus. Isolat LBS4 memiliki kesamaan dengan genus Acinetobacter. DBS1 memiliki kesamaan karakteristik dengan genus Flavobacterium. Isolat SBS2 merupakan genus Alcaligenes. Hasil identifikasi yang telah dilakukan, maka diperoleh empat genus bakteri selulolitik yaitu Lactobacillus, Acinetobacter, Flavobacterium, dan Alcaligenes.

Tabel 6. Hasil uji fisiologis bakteri selulolitik

\begin{tabular}{cccccccccccc}
\hline \multirow{2}{*}{ No } & \multirow{2}{*}{ Kode isolat } & \multicolumn{10}{c}{ Uji fisiologis } \\
\cline { 2 - 14 } & Mot & Kat & Glu & Suk & Lak & SC & MC & Gas & $\mathrm{H}_{2} S$ & Urea \\
\hline 1 & LBS3 & + & + & - & + & + & - & + & - & - & + \\
2 & LBS4 & - & + & - & + & + & + & + & - & - & + \\
3 & DBS1 & - & + & + & + & + & + & + & - & - & + \\
4 & DBS7 & + & + & - & + & + & - & + & - & - & + \\
5 & SBS2 & + & + & + & - & - & + & - & - & - & + \\
6 & SBS6 & + & + & - & + & + & - & + & - & - & + \\
\hline
\end{tabular}

Keterangan: Mot $=$ motilitas; Kat $=$ katalase $;$ Glu $=$ glukosa $;$ Suk sukrosa $;$ Lak $=$ laktosa $;$ SC $=$ simon sitrat; $\mathrm{MC}=$ mac conkey.$+=$ hasil uji positif $;-=$ hasil uji negatif

\section{PEMBAHASAN}

Bakteri selulolitik yang ditemukan dari ketiga lokasi termasuk bakteri aerob. Wafa (2017) menyebutkan bahwa kebanyakan bakteri yang hidup di rizosfer tanaman merupakan bakteri aerob. Kisaran suhu tanah 27-36 ${ }^{\circ} \mathrm{C}$ mendukung untuk pertumbuhan bakteri selulolitik (Indriani, 2008) sehingga 
tergolong bakteri mesofil. Kelembapan tanah memengaruhi aktivitas bakteri selulolitik dalam mendegradasi selulosa yang berkisar antara 45-79\% (Wahyuni, Siti, \& Riza, 2015) dengan rentang $\mathrm{pH}$ 4-9 (Khairiah, Khotimah, \& Mulyadi, 2013). Sehingga dari hasil pengukuran menandakan keberadaan bakteri selulolitik cukup baik.

Sebanyak 19 isolat kandidat selulolitik berhasil diisolasi dari rizosfer kelapa sawit pada media CMCA. Kemampuan bakteri untuk tumbuh pada media CMCA menunjukkan bahwa bakteri tersebut mampu memanfaatkan selulosa sebagai salah satu sumber karbon dan nutrisi bagi pertumbuhannya (Murtiyaningsih \& Hazmi, 2017). Adanya aktivitas selulolitik dapat dideteksi dengan keberadaan zona bening di sekitar koloni setelah diwarnai dengan congo red.

Menurut Choi, Hodgkiss, dan Hyde (2005) isolat yang memiliki aktivitas selulolitik didasarkan dari nilai Indeks Aktivitas Selulolitik (IAS). IAS dikatakan rendah apabila memiliki nilai $\leq 1$, IAS sedang jika nilainya $>1$ dan $<2$ serta tinggi apabila $\geq 2$. Terdapat 3 isolat yang tidak menunjukkan adanya zona bening, yaitu LBS5, SBS3, dan SBS4. Selain itu, pertumbuhan koloni ketiga isolat pada media CMCA hanya berukuran kecil. Hal ini disebabkan perbedaan kemampuan adaptasi isolat dengan medium atau lingkungan hidupnya antara lain suhu, $\mathrm{pH}$, dan sumber nutrisi yang digunakan. Kemampuan tersebut ditentukan oleh gen yang dimilikinya (Soeka \& Triana, 2016).

Aktivitas enzim selulase yang dihasilkan oleh bakteri mempunyai karakteristik yang berbeda-beda, hal ini dipengaruhi oleh beberapa faktor seperti suhu, $\mathrm{pH}$ tempat enzim bekerja, konsentrasi substrat dan waktu inkubasi (Saropah, 2012). Isolat DBS1 dan DBS2 memiliki nilai IAS yang tinggi pada inkubasi 24 jam, sedangkan DBS4 dengan waktu inkubasi 120 jam serta isolat lainnya pada 48 jam. Waktu inkubasi yang menunjukkan aktivitas tertinggi merupakan kondisi saat enzim bekerja secara maksimal pada jangka waktu inkubasi tersebut (Rahayu et al., 2014).

Sebanyak 16 isolat terpilih yang memiliki potensial selulolitik pada uji IAS diujikan kemampuannya dalam menghambat jamur patogen $G$. boninense dengan menggunakan metode dual culture. Jika dilihat dari persentase penghambatan berdasarkan growth inhibition category (GIC) Živković et al. (2010) bakteri selulolitik rizosfer sawit umumnya berada pada skala 0 sampai 2, dimana isolat DBS2 dan SBS5 termasuk skala 0 , karena tidak mampu menghambat jamur patogen $G$. boninense.

Isolat DBS1 memiliki daya antagonis tertinggi dalam menghambat pertumbuhan jamur patogen $G$. boninense yaitu sebesar $40,17 \%$, namun memiliki indeks selulolitik yang rendah. Berbeda dengan LBS1 dan DBS6 memiliki indeks selulolitik yang tinggi, yaitu 4,38 dan 2,81, namun memiliki persentase penghambatan yang lemah $(27,92 \%$ dan $1,16 \%)$. Khaeruni, Satrah, dan Mariadi (2011) bahwa aktivitas enzim selulase yang tinggi tidak menunjukkan adanya korelasi positif dengan kemampuan menghambat patogen tanaman. Hal ini juga sesuai dengan penelitian Harni dan Amaria (2012), bahwa nilai aktivitas enzim yang tinggi tidak selalu berkorelasi positif dengan kemampuan menghambat pertumbuhan jamur patogen. Hal ini dimungkinkan karena adanya mekanisme dalam menekan patogen yang terlibat dalam proses antagonis bakteri, salah satunya dengan menghasilkan senyawa yang dapat berfungsi sebagai inhibitor suatu enzim.

Menurut Novitasari (2013), perbedaan aktivitas penghambatan jamur patogen dengan bakteri selulolitik dapat disebabkan oleh beberapa hal diantaranya: kespesifikan spesies, perbedaan aktivitas selulase bakteri, komposisi selulosa dari dinding sel jamur, dan keberadaan metabolit anti jamur. Wulandari, Zakiyatulyaqin, dan Supriyanto (2012), menyatakan bahwa perbedaan daya antagonis yang dihasilkan diduga karena adanya perbedaan jenis dan jumlah metabolit yang dihasilkan oleh masing-masing isolat bakteri selulolitik yang berfungsi sebagai antifungi terhadap G. boninense.

Hasil uji $\mathrm{T}$ menunjukkan bahwa isolat bakteri selulolitik yang memiliki t hitung yang signifikan dari $\mathrm{T}$ tabel $(4,303)$ yaitu isolat LBS3, LBS4, DBS1, DBS7, SBS2 dan SBS6, sedangkan nilai $\mathrm{T}$ hitung untuk isolat lainnya tidak signifikan. Menurut Tirtana et al. (2013), agen hayati yang memiliki nilai uji $\mathrm{T}$ lebih 
besar dari t tabel, maka berpotensi sebagai antagonis jamur patogen. Keenam isolat dapat dijadikan sebagai antagonis terhadap $G$. boninense. DBS1 memiliki persentase daya hambat yang tertinggi yaitu 40,17 dan berdasarkan uji $\mathrm{T}$ efektif atau berpotensi sebagai antagonis dari G. boninense. Hidayah dan Yulianti (2015) menambahkan bahwa bakteri yang memiliki daya antagonis $\geq 35 \%$ juga mampu dan berpotensi untuk digunakan sebagai agens pengendalian hayati.

Persentase daya hambat pada SBS6 yaitu $13,35 \%$ tergolong lemah namun memiliki nilai $\mathrm{t}$ hitung signifikan yaitu $-6,342$ dengan mekanisme berupa antibiosis yang diduga dapat menekan pertumbuhan $G$. boninense. Hal ini pernah dilaporkan pada penelitian Nasahi, Widiantini, Yulia, Meliansyah, dan Rasisetyo (2017), persentase penghambatan 8,13\% pada Actinobacteria isolat BEK2 secara signifikan $(\mathrm{P}<0,05)$ bersifat antagonis terhadap $G$. boninense. Mekanisme antibiosis dengan terbentuknya zona bening diperkirakan karena adanya senyawa metabolit yang dapat menghambat pertumbuhan jamur patogen $G$. boninense.

Genus Flavobacterium merupakan bakteri selulolitik yang mampu memproduksi berbagai enzim ekstraseluler yang berperan dalam degradasi polimer seperti selulosa, kitin, dan polisakarida (Bernardet \& Bowman, 2006). Salah satu senyawa metabolit sekunder dari Flavobacterium berupa senyawa alkaloid yang berkaitan dengan kemampuan dalam menginaktifkan sistem enzim dan merubah permeabilitas dinding sel jamur (Safriani, Syamsuddin, \& Marlina, 2016). Rizobakteria Flavobacterium sp. mampu menghambat patogen terbawa benih yaitu Phytopthora capsica dan Colletrotichum capsici dengan aktivitas penghambatan sangat tinggi $>75 \%$.

Selain Flavobacterium, diperoleh bakteri selulolitik lain diantaranya Lactobacillus, Acinetobacter, dan Alcaligenes yang memiliki sifat penghambatan terhadap $G$. boninense. Lactobacillus mampu menjadi agen pengendali dengan menghasilkan senyawa metabolit berupa senyawa anti jamur (asam benzeneasetat dan 2-propenil ester) (Wang, Yan, Wang, Zhang, \& Qi, 2012). Acinetobacter mampu menekan pertumbuhan jamur patogen disebabkan adanya senyawa iturin sebagai antijamur (Liu et al., 2007). Adanya kemampuan menghasilkan zat pemacu tumbuh IAA, Alcaligenes berpotensi dijadikan agen biofertilizer (Fauziah, Setiawati, \& Susilowati, 2016).

Bakteri selulolitik sebagai biokontrol alami diharapkan mampu dalam menghambat pertumbuhan cendawan patogen $G$. boninense Berdasarkan keseluruhan percobaan, perlakuan dengan menggunakan bakteri selulolitik menunjukkan aktivitas penghambatan. Isolat bakteri potesial sebagai agens biokontrol terpilih perlu dilakukan uji lanjut dalam penentuan konsentrasi formulasi enzim optimum.

\section{SIMPULAN}

Sebanyak 19 isolat bakteri selulolitik diperoleh dari rizosfer kelapa sawit dengan indeks selulolitik (IS) tertinggi yaitu 4,38 pada isolat LBS1. Berdasarkan uji T dari efektivitas bakteri selulolitik terhadap G.boninense menunjukkan 6 isolat (LBS3, LBS4, DBS1, DBS7, SBS2 dan SBS6) memiliki nilai efektif atau berpotensi sebagai antagonis dengan persentase daya hambat tertinggi sebesar $40,17 \%$ pada DBS1 yang merupakan genus Flavobacterium.

\section{UCAPAN TERIMA KASIH}

Kami mengucapkan terimakasih kepada Direktorat Riset dan Pengabdian Masyarakat (DRPM) UI atas HIBAH PITTA 2017 atas nama Dr. Andi Salamah (Nomor: 619/UN2.R3.1/HKP.05.00/2017) yang telah mendanai penelitian ini.

\section{REFERENSI}

Ali, S. R. A., Yaacob, N. S., Seman, I. A. \& Wahid, M. B. (2004, May 18-19). Oil palm cellulose and lignin degradation of different Ganoderma sp. based on ASTM standard rotting experiment. Paper presented at the International Conference on Pests and Diseases of Importance to the oil palm Industry, Malaysian Oil Palm Board, Kuala Lumpur, Malaysia, Retrieved from https://www.researchgate.net/publication /263093934_Oil_Palm_Cellulose_and_L ignin_Degradation_of_Different_Ganode rma_sp_Based_on_ASTM_Standard_Ro tting_Experiment. 
Bernardet, J. F., \& Bowman, J. P. (2006). The genus Flavobacterium. Prokaryotes, 7 , 481-531.

Choi, Y. W., Hodgkiss. I. J., \& Hyde. K. D. (2005). Enzyme production by endophytes of Brucea javanica. Journal of Agricultural Technology, 1, 55-66

Fauziah, F., Setiawati. M. R., \& Susilowati, D. N.. (2016). Potensi mikroba indigen tanaman teh terhadap pertumbuhan dan ketahanan terhadap penyakit cacar daun (Exobasidium vexans Massee). Jurnal Penelitian Teh dan Kina, 19(1), 115-123.

Fokkema, N. J. (1973). The role of saprophytic fungi in antagonism against Drechslera sorokiniana (Helminthosporium sativum) on agar plates and on rye leaves with pollen. Physiological Plant Pathology, 3(1), 195-205.

Harni, R., \& Amaria, W. (2012). Potensi bakteri kitinolitik untuk pengendalian penyakit busuk pangkal batang lada (Phytophthora capsici). Buletin Riset Tanaman Rempah dan Aneka Tanaman Industri, 3(1), 7-12.

Hidayah, N., \& Yulianti, T. (2015). Uji antagonisme Bacillus cereus dan Rhizoctonia solani terhadap Sclerotium rolfsii. Buletin Tanaman Tembakau, Serat dan Minyak Industri, 7(1), 24068853.

Holt, G. H., Krieg, R. N., Sneath, A. H. P., Staley, T. J., \& Williams, T. S. (1994). Bergey's manual of determinative bacteriology ninth edition. USA: McGraw-Hill Book.

Indriani, Y. (2008). Produksi dan laju dekomposisi serasah daun mangrove apiapi (Avicennia marina Forssk.Vierh) di Desa Lontar, Kecamatan Kemiri, Kabupaten Tangerang, Provinsi Banten (Skripsi sarjana). Prodi Ilmu dan Teknologi Kelautan, Fakultas Perikanan dan Ilmu Kelautan, Institut Petanian Bogor, Bogor, Indonesia.

Kasana, S. C., Richa, S., Hena, D., Som, D., \& Arvind, G. (2008). A rapid and esay method for the detection of microbial cellulases on agar plates using gram's iodine. Current Microbiology, 57(5), 503-507
Khaeruni, A., Satrah, V. N., \& Mariadi. (2011). Isolasi, karakterisasi dan uji antagonis bakteri selulolitik terhadap Phytophthora capsici asal tanaman lada (Piper ningrum L.) secara in-vitro. Jurnal Agroteknologi, 1(3), 156-162.

Khairiah, E., Khotimah, S., \& Mulyadi A. (2013). Karakterisasi dan kepadatan bakteri pendegradasi selulosa pada tanah gambut di Desa Parit Banjar Kabupaten Pontianak. Protobiont, 2(2): 87-92.

Liu, C. H., Chen, X., Liu, T. T., Lian, B., Gu, Y., Caer, V., ... Wang, B. T. (2007). Study of the antifungal activity of Acinetobacter baumanni LCH001 in vitro and identification of its antifungal components. Applied Microbiology and Biotechnology, 76(2), 459-466.

Murtiyaningsih, H., \& Hazmi, M. (2017). Isolasi dan uji aktivitas enzim selulase pada bakteri selulolitik asal tanah sampah. Jurnal of Agricultural Science, 15(2), 293-308.

Nasahi, C., Widiantini F., Yulia, E., Meliansyah, R., \& Rasisetyo, P. (2016, August 27). Isolasi dan deteksi potensi Actinobacteria endofit dalam mengendalikan penyakit busuk pangkal batang pada tanaman kelapa sawit (Ganoderma boninense Pat.). Paper presented at the Seminar Nasional Pengendalian Penyakit Pada Tanaman Pertanian Ramah Lingkungan II, Yogyakarta, Indonesia. Retrieved from http://repository.lppm.unila.ac.id/17364/ 1/5.\%20Prosiding\%20Seminar\%20Nasio nal\%20Joglosemar\%20mahfut.pdf

Novitasari, P. (2013). Isolasi dan identifikasi bakteri kitinolitik penghambat pertumbuhan cendawan patogen asal kokon Cricula trifenestrata (Skripsi sarjana). Departemen Biologi, Fakultas Matematika dan Ilmu Pengetahuan Alam, Institut Pertanian Bogor, Bogor, Indonesia.

Nurfitriani, S., \& Handayanto, E. (2017). Dekomposisi kulit kopi oleh bakteri selulolitik yang diisolasi dari timbunan kulit kopi di Perkebunan Kalibendo, Jawa Timur. Jurnal Tanah dan Sumberdaya Lahan, 4(2), 503-514. 
Purnamasari, D. (2013). Isolasi dan seleksi bakteri selulolitik penghambat pertumbuhan cendawan pada tanaman kelapa sawit (Skripsi sarjana). Departemen Biologi, Fakultas Matematika dan Ilmu Pengetahuan Alam, Institut Pertanian Bogor, Bogor, Indonesia.

Prastya, M. E., Agung, S., \& Endang, K. (2014). Eksplorasi rhizobakteri indigenous tanaman cabai rawit (Capsicum frustescens Linn.) dari pertanian semi organik Desa Batur Kabupaten Semarang sebagai agen hayati pengendali pertumbuhan jamur Fusarium oxysporum f.sp capsici. Jurnal Biologi, 3(3), 18-31.

Rahayu, A, G., Yahyani, Y., \& Puspita, F. (2014). Uji aktivitas selulolitik dari tiga isolat bakteri Bacillus sp. galur lokal Riau. Jurnal Online Mahasiswa Fakultas Matematika dan Ilmu Pengetahuan Unri, 1(2), 19-27.

Rupaedah, B., Amanda, D. V., Indrayanti, R., Asiani, N., Sukmadi, B., Ali, A., Wahid, A., ... Sugianto, M. (2018). Aktivitas Stenotrophomonas rhizophila dan Trichoderma sp. dalam menghambat pertumbuhan Ganoderma boninense. Jurnal Bioteknologi \& Biosains Indonesia, 5(1), 53-63.

Safriani., Syamsuddin., \& Marlina. (2016). Daya hambat rizobakteri terhadap pertumbuhan koloni patogen terbawa benih cabai merah secara in vitro dan pengaruhnya terhadap viabilitas benih. Jurnal Kawista, 1(1), 50-58.

Saropah, D. A. (2012). Penentuan kondisi optimum ekstrak kasar selulase bakteri selulolitik hasil isolasi dari bekatul (Skripsi sarjana). Univeritas Islam Negeri Malang, Malang, Indonesia.

Seprianto. (2017). Isolasi dan penapisan bakteri selulolitik dari berbagai jenis tanah sebagai penghasil enzim selulase. Indonesian Journal of Biotechnology and Biodiversity, 1(2), 64-70.

Soeka, Y. S., \& Triana, E. (2016). Pemanfaatan limbah kulit udang untuk menghasilkan enzim kitinase dari Streptomyces macrosporeus InaCC A454. Jurnal Kimia Terapan Indonesia, 18(1), 91-101.

Tirtana, Z. Y. G., Sulistyowati, L., \& Cholil, A. (2013). Eksplorasi jamur endofit pada tanaman kentang (Solanum tuberosum L.) serta potensi antagonismenya terhadap Phytophthora infestans (Mont.) De Barry penyebab penyakit hawar daun secara in vitro. Jurnal Hama dan Penyakit Tanaman, 1(3), 91-101.

Wafa, A. (2017). Sebaran vertikal mikroba fungsional pada perakaran kelapa sawit dan potensinya sebagai agens pengendalian hayati Ganoderma boninense Pat (Tesis master). Prodi Fitopatologi, Sekolah Pascasarjana Institut Pertanian Bogor, Bogor, Indonesia.

Wahyuni, D., Siti, K., \& Riza, L. (2015). Eksplorasi bakteri selulolitik pada tingkat kematangan gambut yang berbeda di Kawasan Hutan Lindung Gunung Ambawang Kabupaten Kubu Raya. Protobiont, 4(1), 69-76.

Wang, H. K., Yan, Y. H., Wang, J. M., Zhang, H. P., \& Qi, W. (2012). Production and characterization of antifungal compounds produced by Lactobacillus plantarum IMAU10014. Journals Public Library of Science, 7(1), 1-7.

Wulandari, H., Zakiyatulyaqin., \& Supriyanto. (2012). Isolasi dan pengujian bakteri endofit dari tanaman lada (Piper ningrum L.) sebagai antagonis terhadap patogen hawar beludru (Septobasidium sp.). Jurnal Perkebunan dan Lahan Tropika, 2(2), 23-31.

Živković, S., Stojanović, S., Ivanović, Ž., Gavrilović, V., Popović, T., \& Balaž, J. (2010). Screening of antagonistic activity of microorganisms against Colletotrichum Acutatum and Colletotrichum Gloeosporioides. Archives Biological Science Belgrade, 62(3), 611-623. 